\title{
RELATIONSHIP BETWEEN FINANCIAL SATISFACTION AND FINANCIAL LITERACY: EXPLORING GENDER DIFFERENCES
}

Ivona ŠKREBLIN KIRBIŠ

Zagreb School of Economics and Management, Zagreb

Maja VEHOVEC

The Institute of Economics, Zagreb

Zvonimir GALIĆ

Faculty of Humanities and Social Sciences, Zagreb

UDK: 305(497.5):336.7

Izvorni znanstveni rad

Primljeno: 2. 5. 2016.

The goals of this study were to explore gender differences in the components of financial literacy (financial knowledge, financial attitude and financial behavior) and financial satisfaction, and to explore gender differences in the relationship between financial satisfaction and the financial literacy components. Analyses conducted on a data collected on a large and heterogeneous sample of Croatian citizens $(N=900)$ showed that men scored higher on some financial literacy variables and were more financially satisfied. Moreover, in the male subsample there were significantly stronger correlations between financial satisfaction and some financial literacy variables (rational financial attitude, self-assessment of financial management and monitoring expenses) when compared to the female subsample. In addition to demographic variables, significant predictors of financial satisfaction in both gender groups were primarily financial behaviors. Financial attitude component explained additional financial satisfaction variance for men but not for women. Financial knowledge as the third component was not a significant predictor of financial satisfaction for either gender.

Keywords: financial literacy, financial satisfaction, gender differences 
According to the International Network on Financial Education by OECD, financial literacy is "a combination of awareness, knowledge, skill, attitude and behavior necessary to make sound financial decisions and ultimately achieve individual financial wellbeing" (OECD INFE, 2011, p. 3). During the last decade, there has been a growing body of literature on financial literacy issues. Especially important seems to be the work by Lusardi and Mitchell (see Lusardi \& Mitchell, 2014 for an overview) who introduced measures of financial literacy, compared different social groups on them and demonstrated the effects of financial literacy on important economic behaviors. Their work showed that financial literacy is generally low at the population level with some social groups more vulnerable to financial illiteracy. For example, lower levels of financial literacy were observed for women than for men, for young and old in comparison to middle-aged, and for those with lower educational attainment in comparison to the better educated. More importantly, Lusardi and Mitchell (2014) demonstrated that financial literacy is important in economic decisions and showed how costly it is to be financially ignorant. For example, lower levels of financial literacy were related to less frequent saving and retirement planning, more costly mortgages and more often high cost borrowing. Similarly, using two samples of participants from the Netherlands, van Rooij, Lusardi, and Alessie (2011) found that participants who were less financially literate were also less likely to plan and think about their financial future.

This topic has recently been explored in Croatia also (Škreblin Kirbiš, Tomić, \& Vehovec, 2011; Vehovec, Rajh, \& Škreblin Kirbiš, 2015). Results of the latter study, which used the OECD methodology for the measurement of financial literacy, revealed less than satisfying levels of financial literacy among Croatian citizens. Financial literacy levels were significantly related to demographic variables. For example, lower levels of financial literacy were observed among respondents who were less educated, had lower household income, lived in rural areas, and were unemployed at the moment the study was conducted. An interesting pattern of results was observed related to the participants' gender. On the one hand, the gender difference in the financial knowledge component of financial literacy was in favor of men. On the other hand, there were no significant gender differences in the attitude and behavior components. These results were somewhat different from Atkinson and Messy (2012), who conducted an international comparison of financial literacy. They found gender differences in financial knowledge and the attitudinal component of financial literacy with males being more knowledge- 
DRUŠ. ISTRAŽ. ZAGREB GOD. 26 (2017), BR. 2 STR. $165-185$

ŠKREBLIN-KIRBIŠ, I. VEHOVEC, M., GALIĆ, Z.: RELATIONSHIP BETWEEN.. able but females reporting a more rational financial attitude. They also did not find consistent gender differences in the behavioral component of financial literacy across countries.

The objective of this study was to contribute to the financial literacy literature by exploring gender differences in the components of financial literacy, financial satisfaction and the possible moderating effect of gender on the relationship between financial literacy and financial satisfaction in a sample of Croatian participants.

More precisely, with our study we wanted to respond to three research questions:

(1) Do men and women differ in the components of financial literacy as defined by the OECD (i.e., financial knowledge, financial attitudes, and financial behavior)?

(2) Are there gender differences in financial satisfaction?

(3) Are the components of financial literacy differently related to financial satisfaction in two gender groups?

\section{LITERATURE REVIEW AND HYPOTHESIS}

Literature review on financial literacy generally reveals lower levels of financial literacy among females. According to Lusardi and Mitchell (2014), women have significantly lower levels of financial literacy than men, and they chose the "do not know" response much more often than men. Also, the results of research conducted by Cheng, Lin, and Liu (2011) indicated that women on average paid higher costs on loans than men. The authors attributed this gender difference to the differences in behavior, as women were less likely to search for the lowest interest rate. Mahdavi and Horton (2014), using a large sample of graduates from a prestigious liberal college in the US, concluded that the level of financial literacy even among highly educated women was quite low. In accordance with this literature review, we advanced the following hypothesis:

Hypothesis 1:

Men are more financially literate than women.

Even though the research results listed above pointed out lower levels of financial literacy among women, there has been no agreement about what factors contribute to the gender differences. Fonseca, Mullen, Zamarro, and Zissimopoulos (2012) investigated financial literacy and financial decision making among couples with the focus on gender differences. They confirmed lower financial literacy among women and found a positive correlation between the frequency of financial decision making and financial literacy only for men. They found little support for household financial decision's spe- 
DRUŠ. ISTRAŽ. ZAGREB GOD. 26 (2017), BR. 2, STR. 165-185

ŠKREBLIN-KIRBIŠ, I. VEHOVEC, M., GALIĆ, $Z$. RELATIONSHIP BETWEEN... cialization by gender as a possible mechanism underlying the gender differences in financial literacy. Hsu (2011) underlined that gender differences in financial literacy were the result of specialization within the household with females' late adoption of the financial knowledge and skills. Recent work by Farrell, Fry, and Risse (2016) explained women's personal finance behavior with financial self-efficacy - self-perceived ability to deal with financial matters. Women with higher self-efficacy were more likely to use financial products that were forward thinking (e.g., investment, mortgage or savings) than women with lower self-efficacy who tended to use financial products related to debt (e.g., credit card or loan).

While financial literacy can be assessed both objectively and subjectively, financial satisfaction is subjective by definition. Financial satisfaction can be defined as satisfaction with one's current financial situation and it is considered to be a sub-component of general wellbeing (Joo \& Grable, 2004; Murphy, 2013; Gerrans, Speelman, \& Campitelli, 2014). It is usually measured with a single broad question such as "How satisfied are you with your current financial situation?" or with several specific questions such as "How satisfied are you with your savings?" or "How satisfied are you with your assets?". Plagnol (2011) showed that the major determinant of financial satisfaction is income, whose influence on financial satisfaction was mediated through personal financial aspirations. Financial satisfaction is an important concept for the development of the society, as it was shown to be related to consumer choice, job productivity, marital stress and social choice (Joo \& Grable, 2004).

As far as gender differences in financial satisfaction are concerned, a study by Hira and Mugenda (2000) showed that, in comparison to men, women less often reported that their financial situation was better than that of others at the same socioeconomic level. Women were also less satisfied with their ability to handle financial emergencies and their ability to meet long-term goals, and more dissatisfied with their current financial situation. At the same moment, women were more likely than men to be satisfied with their savings. This study also reported inconsistencies between women's financial perceptions and behaviors, which is why the authors proposed the development of financial education programs designed specifically for men and women. Power and Hira's (2004) study on retiree financial satisfaction also reported higher financial satisfaction among men than among women. In sum, though there are some inconsistencies, literature generally reports larger levels of financial satisfaction among men. In accordance with this, our second expectation regarding our study was: 
DRUŠ. ISTRAŽ. ZAGREB GOD. 26 (2017), BR. 2 STR. 165 -185

ŠKREBLIN-KIRBIŠ, I. VEHOVEC, M., GALIĆ, Z.: RELATIONSHIP BETWEEN..
Hypothesis 2:

Men are more financially satisfied than woman.

Regarding the relationship between financial literacy and financial satisfaction, existing literature generally assumes a positive relationship between the two, even though it was not always direct and was observed to be somewhat different for men and women. Murphy (2013) analyzed the relationship between financial literacy and several psychosocial variables (financial satisfaction, hopelessness and religiosity) in the $50+$ age cohort. He found a low positive correlation between financial knowledge and financial satisfaction. A possible explanation for this correlation is that greater financial literacy improves financial satisfaction by helping individuals to develop the skills necessary to deal with their financial matters. Guven (2012) showed that happiness affected financial behavior in a way that happier people saved more, spent less, had lower marginal propensity to consume, and were more future oriented.

A study by Hira and Loibl (2005) showed that employer-based education in financial literacy can improve satisfaction with one's workplace. In their study, the workplace-based financial education stimulated financial literacy and resulted in higher expectations regarding future financial situation and higher workplace satisfaction. Financial literacy as a significant determinant of consumer satisfaction was also reported in a nationwide credit card user survey in Turkey (Akin, Aysan, Ozcelik, \& Yildiran, 2012). Akin et al. found that people who had more financial knowledge and used it when dealing with financial matters reported fewer financial problems. Additionally, financial behaviors related to lower satisfaction of credit card users were unnecessary shopping and credit card delinquency. Another significant determinant of satisfaction was education, while gender, marital status and age were not significant. Robb, Babiarz, and Woodyard (2012) focused on the analysis of demand for personal financial advice in relationship with financial knowledge, satisfaction and confidence. They found that higher objective and subjective financial knowledge and financial satisfaction were associated with using more financial advice in general. Specifically, financial knowledge and satisfaction were positively related to seeking advice about saving, investment and tax planning, while a negative relationship was found for seeking advice about debt.

The effect of financial literacy on financial satisfaction was also explored in Malaysia: Ali, Rahman, and Bakar (2015) reported that financial planning was an important determinant of financial satisfaction. Financial knowledge and the attitude 
DRUŠ. ISTRAŽ. ZAGREB GOD. 26 (2017), BR. 2, STR. 165-185

ŠKREBLIN-KIRBIŠ, I. VEHOVEC, M., GALIĆ, Z.: RELATIONSHIP BETWEEN... towards money were significant antecedents of financial planning. The relationship of financial knowledge and the attitude towards money on financial satisfaction was completely mediated through financial planning. Joo and Grable (2004) proposed a comprehensive model of financial satisfaction determinants. In testing the model the most important determinant of financial satisfaction was financial behavior, followed by financial stress and self-assessed financial knowledge. Those who engaged in more rational financial behaviors experienced less financial stress and those who reported higher financial knowledge were more financially satisfied. Based on the results of their study, the authors concluded that the single best method for improving financial satisfaction was education directed at improving financial behaviors.

The literature review suggests that there is an unquestionable relationship between financial literacy and financial satisfaction. However, the literature on gender differences in the relationship between financial literacy and financial satisfaction seems scarce. Gerrans et al. (2014) explored the relationship between personal financial wellness and personal wellbeing with a focus on financial literacy. The authors found that men ranked higher on financial knowledge and financial satisfaction, while women were better on personal wellbeing, defined as subjective overall assessment of life. For females, the main source of their financial satisfaction was financial status (defined as household income, assets and debt) and for males, it was financial knowledge. There was no relationship between financial knowledge and financial satisfaction for females. The authors also found that financial satisfaction was more important for women's personal wellbeing than for men's personal wellbeing. In our study, we wanted to explore the potential moderating effect of gender on the relationship between financial literacy components and financial satisfaction. Considering the scarcity of research, we had no clear expectations about the exact nature of the relationship, but formulated a research question.

Research Question 1:

Is the relationship between the financial literacy components and financial satisfaction different for men and women?

In sum, from the literature review presented, it seems that there is evidence for gender differences in both financial literacy and financial satisfaction. It is also clear that there is a positive relationship between some financial literacy variables and financial satisfaction even though this effect is not always direct and varies by gender. In this research, we wanted to go one step further and determine which financial literacy vari- 
(1) FIGURE 1

Research model in this study ables are related to financial satisfaction the most and to explore gender differences in this relationship (Figure 1).

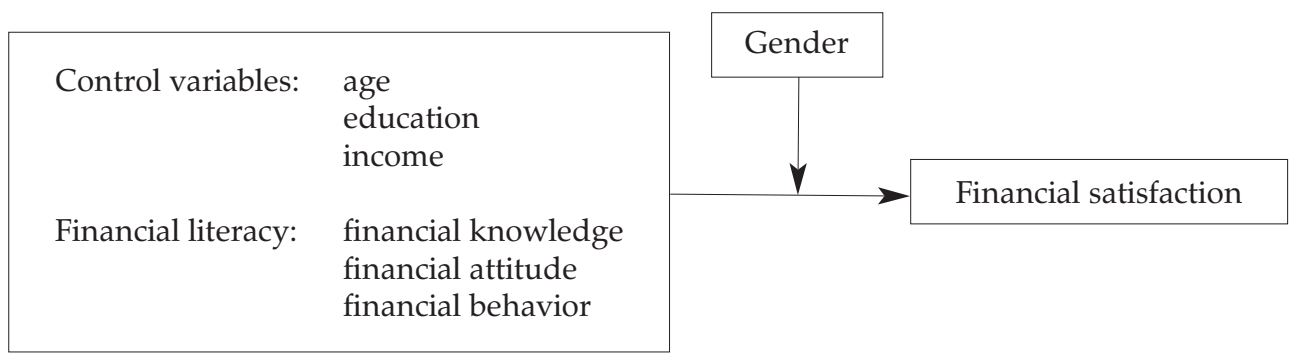

\section{METHODOLOGY}

\section{Participants}

Comparison of the Croatian population and the sample according to gender and age group (percentages) $\rightarrow$ TABLE 1

The total sample included 900 people between 18 and 65 years of age from all over Croatia. There were 300 participants in each of the European Commission's Nomenclature of Territorial Units for Statistics 2 region (according to the division valid from 2007 to 2012: Northwest Croatia, Central Eastern Croatia, Adriatic Croatia) recruited to be representative of the Croatian population in terms of age and gender. Comparison of the sample with the Croatian population regarding gender and age composition is presented in Table 1 . The average respondent is 42.48 years old $(S D=13.51)$, has a high school degree $(M=2.20 ; S D=0.57)$ and has a household income between 5001 HRK and 8000 HRK $(M=4.59 ; S D=2.02)$.

\begin{tabular}{llcc}
\hline & & Population (\%) & Sample (\%) \\
\hline \multirow{2}{*}{ Gender } & Males & 49.8 & 49 \\
& Females & 50.2 & 51 \\
\multirow{4}{*}{ Age group } & $18-24$ & 13.0 & 12.8 \\
& $25-34$ & 21.1 & 20.8 \\
& $35-44$ & 20.7 & 20.6 \\
& $45-54$ & 22.7 & 23.0 \\
& $55-65$ & 22.4 & 22.9
\end{tabular}

\section{Procedure}

The data were collected through a telephone survey. A market research agency collected the data using the CATI (Computer Assisted Telephone Interviewing) method with $25 \%$ of each interviewer's interview being controlled. The telephone interview lasted for about 15 minutes. From those who agreed to participate in the study, $30.1 \%$ completed the whole questionnaire. 
The questionnaire was tailored to national conditions based on the OECD methodology for financial literacy measurement with some additional questions and some variation in composite variables (OECD INFE, 2011).

Financial literacy measure had three components: (a) financial knowledge, (b) financial attitude, and (c) financial behavior.

Financial knowledge scale consisted of seven questions. The questions covered knowledge of the discounted value of mo-ney, simple and compounded interest account, risk and return on investment, inflation and the diversification of savings. A sample item was "You lend $100 \mathrm{HRK}$ to a friend one evening and he gives you 100 HRK back the next day. How much interest has he paid on this loan?". The full list of knowledge questions can be found in Atkinson and Messy (2012) and Vehovec et al. (2015). The score on the knowledge components was calcula-ted as the sum of correct responses. Cronbach's alpha for the scale is 0.42 (0.41 for men and 0.41 for women).

The financial attitude component of financial literacy consisted of three different attitudes: rational financial attitude, self-assessed financial management and risk tendency. Rational financial attitude was composed of three statements that indicate the rational financial position aimed at planning the future and a more careful attitude toward money, with a higher score meaning a more rational financial attitude. Participants had to rate to what extent they agreed (1 - "I completely disagree", - "I completely agree") with the following statements:

- "Money is there to be spent."

- "I find it more satisfying to spend money than to save it for the long term."

- "I tend to live for today and let tomorrow take care of itself".

The total score was calculated as a mean score of reversely coded responses. Cronbach's alpha for the scale is 0.43 (0.45 for men and 0.41 for women).

Self-assessed financial management scale consisted of four items that are self-assessments of the participant's financial management skill. A higher score points to better self-assessed financial management skills. The question was formulated as follows: "On a scale of 1 to 5 , where 1 is not good at all, and 5 is very good, how would you rate yourself on each of the following areas of financial management...

- keeping track of your money?

- making ends meet?

- shopping around to get the best financial product such as loans or insurance rates?

- staying informed about financial issues?" 
DRUŠ. ISTRAŽ. ZAGREB GOD. 26 (2017), BR. 2 STR. $165-185$

ŠKREBLIN-KIRBIŠ, I. VEHOVEC, M., GALIĆ, Z.: RELATIONSHIP BETWEEN..
The total score was calculated as a mean score of the listed items. Cronbach's alpha for the scale is 0.55 ( 0.58 for males and 0.52 for females).

Risk tendency was measured by a single item and it refers to a participant's readiness to risk some of their money when saving or making an investment, with a higher score meaning a higher risk propensity ("I am prepared to risk some of my own money when saving or making an investment."). Participants had to rate to what extent they agreed $(1-\mathrm{com}$ pletely disagree, 5 - completely agree).

Financial behavior, as the third financial literacy component, consisted of five behaviors: saving, investment, overdraft, shopping around and monitoring expenses. Saving was measured with two items, with a higher score implying saving in any way and being able to cover living expenses for a longer time. Two items were formulated as follows:

"In the past 12 months have you been [personally] saving money in any of the following ways: a) Saving cash at home or in your wallet; b) Building up a balance of money in your bank account, saving cash at home or in a wallet; c) Paying money into a savings account; d) Giving money to family to save on your behalf."

"If you lost your main source of income, how long could you continue to cover living expenses, without borrowing any money? a) Less than a week; b) At least a week, but not one month; c) At least one month, but not three months; d) At least three months, but not six months; e) More than six months."

We combined the two variables into a single score in order to get one saving indicator. The combined saving variable was coded as follows: 0 - does not save in any way and could not cover living expenses for 3 months; 1 - does not save in any way but could cover living expenses for 3 months or more / does save in at least one way but could not cover living expenses for 3 months; 2 - does save in at least one way and could cover living expenses for 3 months or more.

Investment behavior was assessed with the same question as saving behavior with a focus on specific answers: "In the past 12 months have you been [personally] saving money in any of the following ways: a) Buying financial investment products, other than pension funds [give examples such as bonds, investment trusts, stocks and shares]; b) Or in some other way (i.e. buying a real estate)".

The answers were coded as follows: 0 - no investment of such kind; 1 - at least one kind of investment.

The question measuring shopping around reads as follows: "Which of the following statements best describes how you last chose a financial product?" with possible answers 
DRUŠ. ISTRAŽ. ZAGREB GOD. 26 (2017), BR. 2, STR. $165-185$

ŠKREBLIN-KIRBIŠ, I. VEHOVEC, M., GALIĆ, Z.: RELATIONSHIP BETWEEN.. being a) I considered several products from different companies before making my decision; b) I considered the various products from one company; c) I didn't consider any other products at all; d) I looked around but there were no other products to consider."

The variable was coded as follows: 1 - no consideration of other products before making a decision (answer c), 2 consideration of other products before making a decision (answers $a, b$ and $d$ ).

A higher score on overdraft implies being overdrawn on one's day to day bank account more often. The question was formulated as follows: "How often have you been overdrawn on your day to day bank account in the last 12 months?" with possible answers being 1 - never, 2 - sometimes, and 3 - continually.

Monitoring expenses was measured through the question: "Which ONE of the following best describes the extent to which you personally monitor your regular expenses?" with possible answers being 1 - I don't keep an eye on expenses at all, 2 - I keep my eye on expenses a bit, 3 - Without keeping written records, I keep a fairly close eye on expenses, 4 - I use written records to keep a close eye on expenses.

Financial satisfaction was measured with a single item: "Overall, thinking of your assets, debts and savings, how satisfied are you with your current personal financial condition?". The response scale ranged between 1 (not at all satisfied) and 5 (extremely satisfied).

Demographic variables used in this survey were gender, age, education and income. Gender was coded as follows: 1 male and $2-$ female. Age was measured in years. Education was coded as follows: 1 - elementary school degree or less, 2 - secondary school degree and 3 - university degree or higher. Income was assessed with the item: "Could you please tell me your average monthly household income (HRK)"? Possible answers were: 1 - up to 2000, 2 - 2001-3500, 3 - 3501-5000, 4 5001-6500, 5 - 6501-8000, 6 - 8001-10000 7 - 10000-15000, 8 15001-20000, 9 - more than 20000.

\section{Data analyses}

Gender differences in financial literacy and financial satisfaction were tested using the t-test for independent samples. Correlations between financial literacy, financial satisfaction and demographic variables were quantified with the Pearson correlation coefficient. Gender differences for correlations between financial satisfaction and financial literacy variables were tested using the Fisher r-to-z calculation. In order to explore the relationship between financial satisfaction and the components of financial literacy simultaneously (with age, educa- 
DRUŠ. ISTRAŽ. ZAGREB GOD. 26 (2017), BR. 2, STR. 165-185

ŠKREBLIN-KIRBIŠ, I. VEHOVEC, M., GALIĆ, Z.: RELATIONSHIP BETWEEN.. tion and income as control variables) we used multiple linear regression analysis, the enter method, separately for each gender group. In the regression analyses, the criterion variable was financial satisfaction while predictor variables were entered in four blocks: one block of demographic variables and three blocks of financial literacy components - knowledge, attitudes and behaviors. The moderating effect of gender on the relationship between financial literacy and financial satisfaction using moderated multiple regression analysis has also been tested. Our data is purely correlational and does not allow conclusions about causality. However, the classification of financial satisfaction as a criterion variable is based on findings from cited research (Joo \& Grable, 2004; Akin et al., 2012; Ali et al., 2015; Gerrans et al., 2014).

\section{RESULTS AND DISCUSSION}

\section{Descriptive statistics and gender differences}

Descriptive statistics for the overall sample as well as for men and women separately is shown in Table 2. As far as the demographic variables are considered, the only significant difference was in average monthly household income, with men reporting higher income than women. Men and women in our sample did not differ significantly in age or education level.

Significant differences between genders were observed in each of the financial literacy components (i.e., knowledge, attitude and behavior), but not in all measured variables. In particular, there was a significant difference in financial knowledge with men scoring higher on the financial knowledge test than women. While men and women differed significantly in the self-assessment of their financial management (females reported better financial management skills than men), gender differences were not observed in rational financial attitude or tendency towards risk. When it comes to financial behavior, the pattern of differences was mixed. On the one hand, men invested more and used overdraft less often than women. On the other hand, women reported keeping a closer eye on their expenses than men. We did not observe significant gender differences in saving or shopping around.

Lower financial knowledge among women is quite consistently reported in literature (see Lusardi \& Mitchell, 2007, 2011; Atkinson \& Messy, 2012). Our results are less consistent with the literature related to the gender differences in the attitudinal and the behavioral component of financial literacy. In an international comparison of gender differences, Atkinson and Messy (2012) reported higher rational financial attitude among women than among men, and inconsistent gender differences across countries in financial behavior. In our 
DRUŠ. ISTRAŽ. ZAGREB GOD. 26 (2017), BR. 2, STR. 165-185

ŠKREBLIN-KIRBIŠ, I. VEHOVEC, M., GALIĆ, Z. RELATIONSHIP BETWEEN.. study, women were shown to be less financially knowledgeable, invested less and used overdraft more often, which reveals them as a more vulnerable gender group when it comes to financial literacy. However, at the same time, there were aspects of financial literacy where women fared better than men: they assessed their own financial management skills better and monitored their expenses more closely than men. Therefore, we confirmed hypothesis 1 only partially.

\begin{tabular}{|c|c|c|c|c|c|c|c|c|}
\hline \multirow[b]{2}{*}{ Variables } & \multirow[b]{2}{*}{ Min-max } & \multicolumn{2}{|c|}{$\begin{array}{c}\text { Overall } \\
\text { sample }\end{array}$} & \multicolumn{2}{|r|}{ Males } & \multicolumn{2}{|c|}{ Females } & \multirow{2}{*}{$\begin{array}{l}\text { Gender } \\
\text { differences } \\
t(d f)^{*}, p\end{array}$} \\
\hline & & $M$ & $S D$ & $M$ & $S D$ & $M$ & $S D$ & \\
\hline \multicolumn{9}{|l|}{ Demographic variables } \\
\hline Age & $18-65$ & 42.48 & 13.51 & 42.31 & 13.57 & 42.64 & 13.47 & $0.37(898), 0.71$ \\
\hline Education group & $1-3$ & 2.20 & 0.57 & 2.22 & 0.54 & 2.18 & 0.60 & $1.29(895), 0.20$ \\
\hline Income group & $1-10$ & 4.59 & 2.02 & 4.90 & 1.96 & 4.31 & 2.04 & $4.03(754),<0.01$ \\
\hline \multicolumn{9}{|l|}{ Financial literacy } \\
\hline $\begin{array}{l}\text { Knowledge } \\
\text { Attitude }\end{array}$ & $0-7$ & 4.93 & 1.41 & 5.21 & 1.35 & 4.67 & 1.41 & $5.91(898),<0.01$ \\
\hline $\begin{array}{l}\text { Attitude } \\
\text { Rational } \\
\text { financial attitude } \\
\text { Self-assessed fi- }\end{array}$ & $1-5$ & 3.17 & 0.90 & 3.13 & 0.91 & 3.20 & 0.88 & $1.11(879), 0.27$ \\
\hline nancial management & it $1-5$ & 3.70 & 0.81 & 3.62 & 0.82 & 3.78 & 0.89 & $2.89(866),<0.01$ \\
\hline Risk tendency & $1-5$ & 2.93 & 1.42 & 3.02 & 1.42 & 2.85 & 1.42 & $1.73(886), 0.08$ \\
\hline \multicolumn{9}{|l|}{ Behavior } \\
\hline Saving & $0-2$ & 1.09 & 0.78 & 1.14 & 0.78 & 1.04 & 0.77 & $1.82(854), 0.07$ \\
\hline Investment & $0-1$ & 0.11 & 0.31 & 0.13 & 0.34 & 0.09 & 0.28 & $2.09(898),<0.05$ \\
\hline Overdraft & $1-3$ & 1.79 & 0.81 & 1.71 & 0.79 & 1.86 & 0.82 & $2.90(877),<0.01$ \\
\hline Shopping around & $1-2$ & 1.68 & 0.47 & 1.70 & 0.46 & 1.66 & 0.47 & $1.23(827), 0.22$ \\
\hline Monitoring expenses & S $1-4$ & 3.08 & 0.72 & 2.98 & 0.74 & 3.18 & 0.70 & $4.12(896),<0.01$ \\
\hline Financial satisfaction & $1-5$ & 3.12 & 1.08 & 3.27 & 1.05 & 2.97 & 1.09 & $4.13(894),<0.01$ \\
\hline
\end{tabular}

* Degrees of freedom differed between the comparisons due to missing data.

(1) TABLE 2

Descriptive statistics for overall sample, male and female subsamples and comparison between the two subsamples ${ }^{1}$
Men and women differ significantly in the criterion variable, with men being more satisfied with their financial situation than women. This result is in line with previous research on this topic (Hira \& Mugenda, 2000; Power \& Hira, 2004; Gerrans et al., 2014) and confirms hypothesis 2 . In order to understand financial satisfaction, in particular women's financial satisfaction that was lower than men's, it seems important to explore the variables that are related to financial satisfaction while taking into consideration the gender differences.

\section{Correlation analyses}

Correlations between the study variables are shown in Table 3 separately for the gender subsamples. For both males and females, significant correlations that were moderate in size 
DRUŠ. ISTRAŽ. ZAGREB GOD. 26 (2017), BR. 2 STR. 165-185

ŠKREBLIN-KIRBIŠ, I VEHOVEC, M., GALIĆ, Z.: RELATIONSHIP BETWEEN.. between saving and financial satisfaction. Participants who had higher household income and saved more reported higher financial satisfaction. Additionally, when looking only at the male subsample, significant correlations revealed that those more financially satisfied were the ones who held a more rational financial attitude, reported better financial management skills, had higher risk tendency, invested more, used overdraft less often, and who monitored their expenses more tightly. In the female subsample, there were fewer significant correlations. Financially more satisfied were the women who were younger, more educated, who invested more, and used overdraft less often. Though significant, all the mentioned correlations were relatively low in size.

Previous research documented that more knowledge is related to higher satisfaction (Akin, et al., 2012; Murphy, 2013). Gerrans et al. (2014) also reported a relationship between financial knowledge and financial satisfaction, but only for males and not for females. In contrast to these findings, when the financial knowledge - financial satisfaction correlation was analyzed, no significant relationship between the two variables either for men or for women was found. Considering that the correlation between financial knowledge and financial satisfaction when found is generally quite low and sometimes even non-significant, the boundary conditions for that relationship (i.e., possible moderating effects) should be more thoroughly explored.

For correlations between financial literacy and financial satisfaction variables, the significance of the differences in correlations between financial literacy and financial satisfaction using the Fisher r-to-z calculations was tested and several significant differences were found. Financial satisfaction was more strongly correlated with rational financial attitude $(\mathrm{z}=-4.02, p<0.01)$, self-assessment of financial management $(\mathrm{z}=2.41, p<0.05)$ and monitoring expenses $(\mathrm{z}=3.00, p<0.01)$ for men than for women. Based on this finding it seems that, when compared to women, men's financial satisfaction is more strongly related to some aspects of their financial attitudes and financial behavior. It is not certain whether males are more financially satisfied because they scored higher on these components of financial literacy, or they score higher because of their higher financial satisfaction. In order to explore the causal nature of this relationship, the best methodological approach for future research would be an experimental design (e.g., training in monitoring expenses). Furthermore, considering the significantly smaller correlations between financial satisfaction and financial literacy variables for females, possibilities for new research are opened up with the aim of detecting additional aspects of financial attitudes or financial behavior that could be important determinants of female financial satisfaction. 


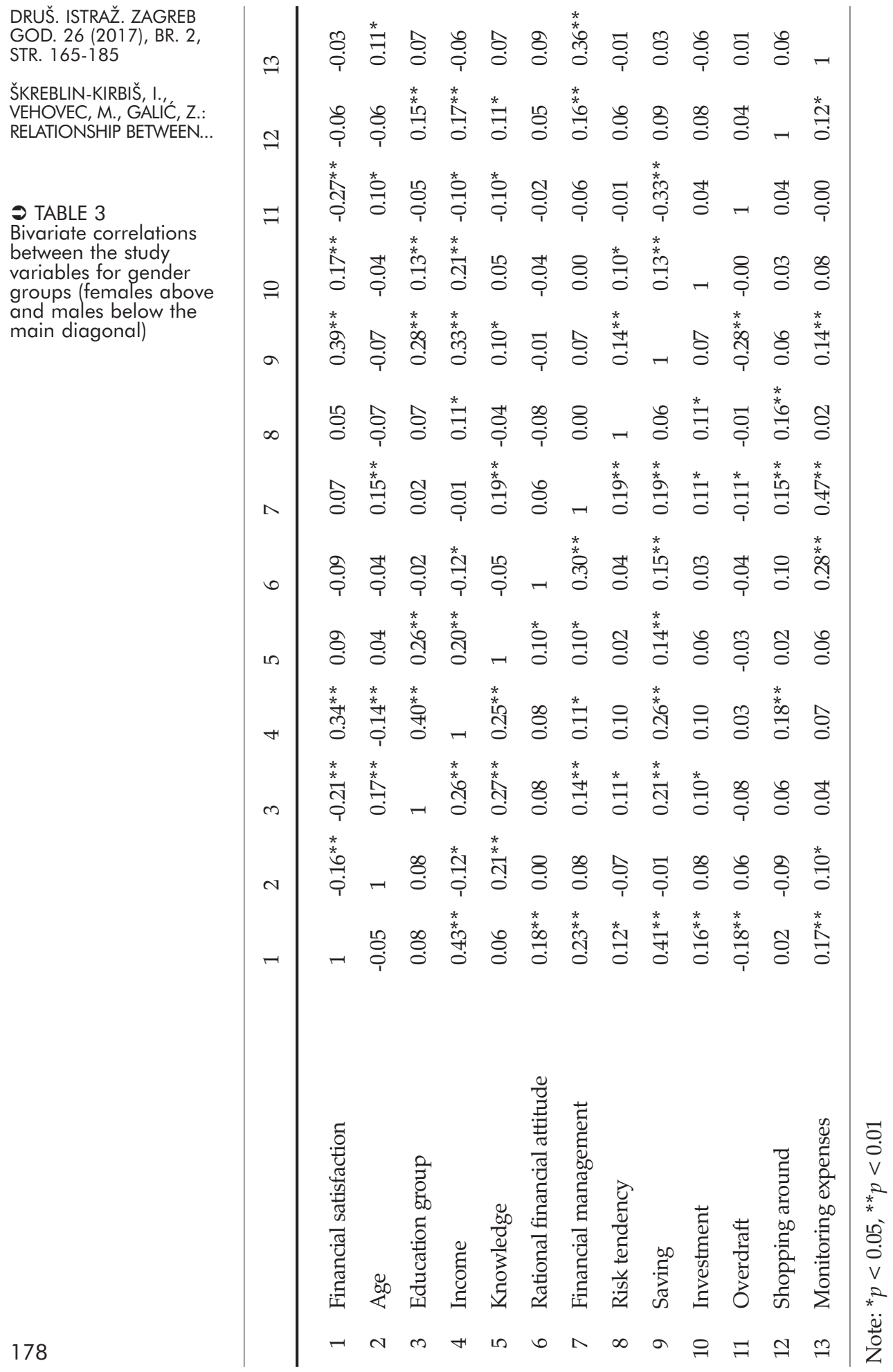




\section{Regression analysis - gender interaction in explaining financial satisfaction}

In order to better understand the gender differences in the relationship between financial literacy components and financial satisfaction, hierarchical multiple regressions were performed. It was believed that, in addition to examining bivariate relationships, simultaneous testing of control variables and the financial literacy components should be performed. Only in this way the unique contributions of financial literacy components, controlled for their interrelations with the demographic variables and other components of financial literacy, could be estimated. When considering the relationship between financial literacy and financial satisfaction separately for men and women (Table 4), we notice several gender differences. The overall regression model explained more financial satisfaction variance for men $(34 \%)$ than women $(23 \%)$. The demographic variables (income in particular) explained $17 \%$ of this variance for men, and $12 \%$ for women. The financial attitudes added to the explanation more in the male $(7 \%)$ than in the female subsample $(1 \%)$, with significant predictors being different for men (rational financial attitude and financial management were positively related to the criterion) and women (no significant attitude predictors). The financial behaviors explained an additional 13\% of the variance in both subsamples, but significant predictors differed between the gender groups. More statistically significant predictors for men were saving and investment (both positive), and saving, investment (both positive), and less overdraft (negative) for women. An unexpected negative relationship was observed for shopping around in the female sample, but considering that its bivariate correlation with financial satisfaction was non-significant, its significance as a predictor probably follows from its intercorrelations with other predictors and represents a suppressor effect. The financial behavior component explained most of the financial satisfaction variance. This was followed by financial attitudes, while financial knowledge was not shown to be a significant predictor of financial satisfaction. The regression model used is in line with Joo and Grable's (2004) model, according to which the single best method for improving financial satisfaction is improvement of financial behaviors. Additionally, the results of our research showed that some predictors of financial satisfaction are gender specific.

As a more strict test of the differential relationship between the financial literacy components and financial satisfaction between the two gender groups, a moderated multiple regression analysis was also performed. First, the continuous 
DRUŠ. ISTRAŽ. ZAGREB GOD. 26 (2017), BR. 2, STR. $165-185$

ŠKREBLIN-KIRBIŠ, I. VEHOVEC, M., GALIĆ, Z.: RELATIONSHIP BETWEEN... predictors were standardized in order to avoid multi-collinearity problems. Interaction terms were calculated as products between gender and the standardized predictors. Variables were entered into equations in two blocks. In the first block, the demographic variables as controls (including gender) were entered and all the financial literacy variables, and, in the second block, the interaction terms.

\begin{tabular}{|c|c|c|c|c|c|c|c|c|}
\hline \multirow[b]{2}{*}{ Predictors } & \multicolumn{4}{|l|}{ Males } & \multicolumn{4}{|c|}{ Females } \\
\hline & $\begin{array}{l}\text { B } \\
\text { block } \\
1\end{array}$ & $\begin{array}{l}\text { B } \\
\text { block } \\
2\end{array}$ & $\begin{array}{l}\text { B } \\
\text { block } \\
3\end{array}$ & $\begin{array}{l}\text { B } \\
\text { block } \\
4\end{array}$ & $\begin{array}{l}\text { B } \\
\text { block } \\
1\end{array}$ & $\begin{array}{l}\text { B } \\
\text { block } \\
2\end{array}$ & $\begin{array}{l}\text { B } \\
\text { block } \\
3\end{array}$ & $\begin{array}{l}\text { B } \\
\text { block } \\
4\end{array}$ \\
\hline \multicolumn{9}{|l|}{ Demographic variables } \\
\hline Age & 0.06 & 0.08 & 0.06 & 0.06 & -0.07 & -0.07 & -0.08 & -0.10 \\
\hline Education group & 0.04 & 0.04 & 0.00 & 0.05 & 0.00 & -0.01 & 0.00 & -0.04 \\
\hline Income & $0.41^{* *}$ & $0.41^{* *}$ & $0.40^{* *}$ & $0.34^{* *}$ & * $0.33^{* *}$ & $0.33^{* *}$ & $0.33^{* *}$ & $0.23^{* *}$ \\
\hline \multicolumn{9}{|l|}{ Financial literacy - knowledge } \\
\hline Knowledge & & -0.06 & -0.07 & -0.08 & & 0.02 & 0.01 & -0.01 \\
\hline \multicolumn{9}{|l|}{ Financial literacy - attitude } \\
\hline Rational financial attitude & & & $0.11^{*}$ & $0.10^{*}$ & & & -0.06 & -0.07 \\
\hline Financial management & & & $0.19^{* *}$ & $0.12^{*}$ & & & 0.05 & 0.05 \\
\hline Risk tendency & & & 0.07 & 0.07 & & & -0.01 & -0.05 \\
\hline \multicolumn{9}{|l|}{ Financial literacy - behavior } \\
\hline Saving & & & & $0.31^{* *}$ & & & & $0.27^{* *}$ \\
\hline Investment & & & & $0.11^{*}$ & & & & $0.11^{*}$ \\
\hline Overdraft & & & & -0.08 & & & & $-0.16^{* *}$ \\
\hline Shopping around & & & & -0.06 & & & & $-0.11^{*}$ \\
\hline Monitoring expenses & & & & 0.03 & & & & -0.03 \\
\hline \multicolumn{9}{|l|}{ Model summary } \\
\hline$R$ & $0.42^{* *}$ & $0.42^{* *}$ & $0.49^{* *}$ & $0.61^{* *}$ & * $0.35^{* *}$ & 0.35 & $0.36^{* *}$ & $0.51^{* *}$ \\
\hline Adjusted $R^{2}$ & 0.17 & 0.17 & 0.23 & 0.34 & 0.12 & 0.11 & 0.11 & 0.23 \\
\hline$R^{2}$ change & $0.17^{* *}$ & 0.00 & $0.07^{* *}$ & $0.13^{* *}$ & ${ }^{*} 0.12^{* *}$ & 0.00 & 0.01 & $0.13^{* *}$ \\
\hline
\end{tabular}

Note: ${ }^{*} p<0.05,{ }^{* *} p<0.01$

(1) TABLE 4

Regression analysis results of predicting financial satisfaction for male and female sample
The interaction terms block was marginally significant in predicting financial satisfaction $(p=0.051)$. Among the predictors in the block, the interaction between rational financial attitude and gender was significant. This suggests that the dynamics between financial satisfaction and this particular aspect of financial literacy is gender specific. In order to understand the exact nature of the interaction, the lines reflecting the relationship between rational financial attitude and financial satisfaction were plotted separately for male and female participants (Figure 2). For both groups, their scores on financial satisfaction for the participants that were one standard deviation below and above the mean on rational financial attitude were calculated and plotted. Men holding more rational 
DRUŠ. ISTRAŽ. ZAGREB GOD. 26 (2017), BR. 2 STR. 165 -185

ŠKREBLIN-KIRBIŠ, I. VEHOVEC, M., GALIĆ, Z.: RELATIONSHIP BETWEEN..

FIGURE 2 Relationship between rational financial attitude and financial satisfaction for males and females financial attitudes tend to be more satisfied with their financial situation. The relationship works in the opposite direction for females: women holding a more rational financial attitude tend to be less satisfied with their financial situation. Though separate regression analyses shown in Table 4 suggested more interaction effects, only the interaction between rational financial attitude and gender was shown to be significant. A probable reason for this finding can be attributed to the influence of the measurement error on the statistical power of our analyses to detect significant effects (Aguinis, 1995).

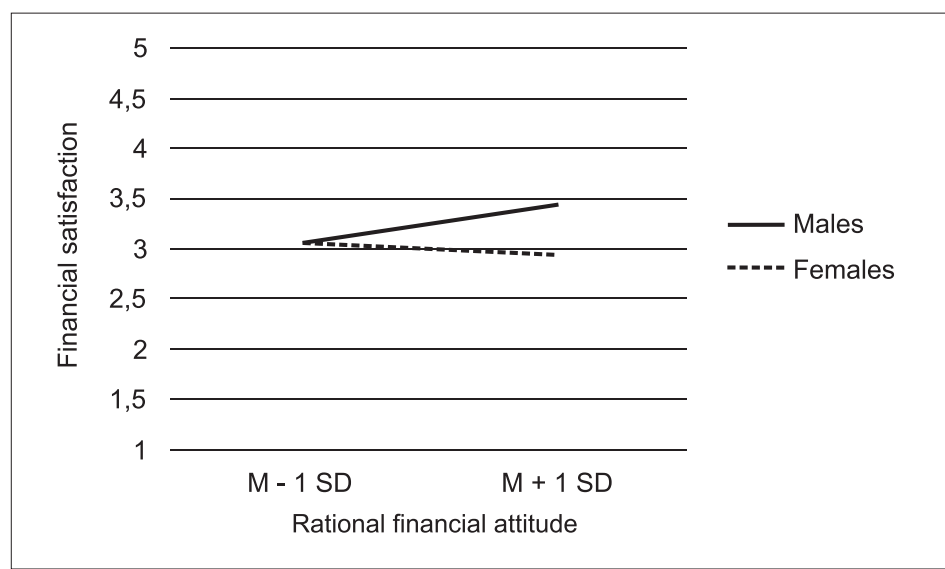

\section{Research implications}

The research findings imply that educational programs aimed at improving financial literacy should focus strongly on the behavioral component, in particular on saving and investment behavior. Individuals should be encouraged to save and invest more in order to increase their financial satisfaction.

Moreover, educational programs should be tailored to accommodate gender differences in financial knowledge. They could incorporate a review and discussion of gender differences in financial literacy and financial satisfaction. In such a way, self-awareness of an individual's strengths and weaknesses might be encouraged. Women could learn from men about areas in which they score better on financial literacy such as knowledge, investment and using overdraft, while men could learn from women about self-management skills and monitoring expenses.

When designing educational programs for men, a strong focus should be on the encouragement of a rational financial attitude. We should be careful with such an approach for females before understanding more about the mechanisms underneath the relationship of financial attitude and financial satisfaction. 


\section{Research limitations}

The correlational design used in this study does not allow for any causal conclusions. In order to investigate the possible causal effects between financial literacy and financial satisfaction, experimental and/or longitudinal design should be employed. For example, random samples of participants should be assigned to various educational or control conditions and the effects of education on financial behavior and financial satisfaction tracked during a certain time period.

Another important limitation is related to the measurement of the constructs employed in this study. For example, several constructs were measured with single-item measures and internal consistency of those that consisted of several items was mediocre (Cronbach alpha ranged between 0.41 and 0.58 for scale variables). However, the measurement problem is not unique to this study, but typical of the studies that deal with financial literacy issues. Considering that this field of research is still in its infancy, future research should be oriented towards the development of instruments for financial literacy measurement.

Another limitation of this study is related to the sample and generalizability of the findings. Similar to other research that is being conducted on samples from general population using CATI methodology, it is questionable to what extent participants who accepted to participate in the survey and completed it represent the whole population. However, it must be emphasized that the sample in this study was relatively large and reflects well the population in terms of gender, age group and region. Considering the trend of decline in the response rate in telephone surveys (Curtin, Presser, \& Singer, 2005), as well as the nature of the topic, a "face to face" survey should be considered in future studies.

\section{CONCLUSION}

This study reveals that women are less financially knowledgeable, invest less and use overdraft more often, making them the more vulnerable gender group in terms of financial literacy. However, at the same time, there are aspects of financial literacy where women score better than men: they estimate their own financial management skills better and monitor their expenses more closely than men. This study also shows that women are less financially satisfied when compared to men.

The bivariate relationships between the financial literacy components and financial satisfaction are different for men and women. When compared to women, men's financial satisfaction is more strongly related to some aspects of financial 
DRUŠ. ISTRAŽ. ZAGREB GOD. 26 (2017), BR. 2, STR. $165-185$

ŠKREBLIN-KIRBIŠ, I RELATIONSHIP BETWEEN.. VEHOVEC, M., GALIĆ, Z.:

literacy such as rational financial attitude, self-assessment of financial management and monitoring expenses. Multivariate analyses revealed that for financial satisfaction, the most important component of financial literacy was financial behavior, for both females and males. However, the pattern of the relationship between the financial literacy components and financial satisfaction is somewhat different for the two gender groups.

1 A two way ANOVA was conducted in order to test for possible interaction between the effects of gender and education level on financial satisfaction and all financial literacy components. Except for risk tendency, the interaction terms were non-significant in all other cases, indicating that the interplay between education and gender probably did not influence our findings.

\section{REFERENCES}

Aguinis, H. (1995). Statistical power problems with moderated multiple regression in management research. Journal of Management, 21(6), 1141-1158. https://doi.org/10.1016/0149-2063(95)90026-8

Akin, G. G., Aysan, A. F., Ozcelik, S., \& Yildiran, L. (2012). Credit card satisfaction and financial literacy: Evidence from an emerging market economy. Emerging Markets Finance and Trade, 48(S5), 103-115. https://doi.org/10.2753/REE1540-496X4806S508

Ali, A., Rahman, M., \& Bakar, A. (2015). Financial satisfaction and the influence of financial literacy in Malaysia. Social Indicators Research, 120(1), 137-156. https://doi.org/10.1007/s11205-014-0583-0

Atkinson, A., \& Messy, F. (2012). Measuring financial literacy. OECD Working Papers on Finance, Insurance and Private Pensions. https://doi.org/10.1787/5k9csfs90fr4-en

Cheng, P., Lin, Z., \& Liu, Y. (2011). Do women pay more for mortgages? Journal of Real Estate Finance and Economics, 43(4), 423-440. https://doi.org/10.1007/s11146-009-9214-y

Curtin, R., Presser, S., \& Singer, E. (2005). Changes in telephone survey nonresponse over the past quarter century. Public Opinion Quarterly, 69(1), 87-98. https://doi.org/10.1093/poq/nfi002

Farrell, L., Fry, T. R. L., \& Risse, L. (2016). The significance of financial self-efficacy in explaining women's personal finance behaviour. Journal of Economic Psychology, 54, 85-99. https://doi.org/10.1016/j.joep. 2015.07.001

Fonseca, R., Mullen, K. J., Zamarro, G., \& Zissimopoulos, J. (2012). What explains the gender gap in financial literacy? The role of household decision making. Journal of Consumer Affairs, 46(1), 90-106. https://doi.org/10.1111/j.1745-6606.2011.01221.x

Gerrans, P., Speelman, C., \& Campitelli, G. (2014). The relationship between personal financial wellness and financial wellbeing: A structural equation modelling approach. Journal of Family and Economic Issues, 35(2), 145-160. https://doi.org/10.1007/s10834-013-9358-z 
DRUŠ. ISTRAŽ. ZAGREB GOD. 26 (2017), BR. 2, STR. $165-185$

ŠKREBLIN-KIRBIŠ, I. VEHOVEC, M., GALIĆ, Z. RELATIONSHIP BETWEEN..
Guven, C. (2012). Reversing the question: Does happiness affect consumption and savings behavior? Journal of Economic Psychology, 33(4), 701-717. https://doi.org/10.1016/j.joep.2012.01.002

Hira, T. K., \& Loibl, C. (2005). Understanding the impact of employer-provided financial education on workplace satisfaction. Journal of Consumer Affairs, 39(1), 173-194. https://doi.org/10.1111/j.174566 06.2005.00008.x

Hira, T. K., \& Mugenda, O. M. (2000). Gender differences in financial perceptions, behaviors and satisfaction. Journal of Financial Counselling and Planning, 13(2), 86-92.

Hsu, J. W. (2011). Aging and strategic learning: The impact of spousal incentives on financial literacy. FEDS Working Paper No. 2011-53. SSRN Electronic Journal. https://doi.org/10.2139/ssrn.1969411

Joo, S., \& Grable, J. E. (2004). An exploratory framework of the determinants of financial satisfaction. Journal of Family and Economic Issues, 25(1), 25-50. https://doi.org/10.1023/B:JEEI.0000016722.37994.9f

Lusardi, A., \& Mitchell, O. S. (2007). Financial literacy and retirement preparedness: Evidence and implications for financial education. Business Economics, 42(1), 35-44.

Lusardi, A., \& Mitchell, O. S. (2011). Financial literacy around the world: An overview. Journal of Pension Economics and Finance, 10(04), 497-508. https://doi.org/10.1017/S1474747211000448

Lusardi, A., \& Mitchell, O. S. (2014). The economic importance of financial literacy: Theory and evidence. Journal of Economic Literature, 52(1), 5-44. https://doi.org/10.1257/jel.52.1.5

Mahdavi, M., \& Horton, N. J. (2014). Financial knowledge among educated women: Room for improvement. Journal of Consumer Affairs, 48(2), 403-417. https://doi.org/10.1111/joca.12032

Murphy, J. L. (2013). Psychosocial factors and financial literacy. Social Security Bulletin, 73(1), 73-81.

OECD INFE (2011). Measuring financial literacy: Questionnaire and guidance notes for conducting an internationally comparable survey of financial literacy. Paris: OECD Available at http://www.oecd.org/finance/finan cial-education/49319977.pdf

Plagnol, A. C. (2011). Financial satisfaction over the life course: The influence of assets and liabilities. Journal of Economic Psychology, 32(1), 45-64. https://doi.org/10.1016/j.joep.2010.10.006

Power, M. L., \& Hira, T. K. (2004). University-provided retirement planning support and retiree financial satisfaction during retirement: Differences by gender, job classification, and planning behavior. Risk Management $\mathcal{E}$ Insurance Review, 7(2), 121-149. https://doi.org/ 10.1111/j.1098-1616.2004.00041.x

Robb, C. A., Babiarz, P., \& Woodyard, A. (2012). The demand for professionals' advice: The role of financial knowledge, satisfaction, and confidence. Financial Services Review, 21(4), 291-305.

Škreblin Kirbiš, I., Tomić, I., \& Vehovec, M. (2011). Mirovinska pismenost i štednja za treću životnu dob (Pension literacy and savings for the third age). Revija za socijalnu politiku, 18(2), 127-148. https://doi. org/10.3935/rsp.v18i2.1004 
DRUŠ. ISTRAŽ. ZAGREB GOD. 26 (2017), BR. 2, STR. 165-185

ŠKREBLIN-KIRBIŠ, I. VEHOVEC, M., GALIĆ, Z.: RELATIONSHIP BETWEEN..
Van Rooij, M. C., Lusardi, A., \& Alessie, R. J. (2011). Financial literacy and retirement planning in the Netherlands. Journal of Economic Psychology, 32(4), 593-608. https://doi.org/10.1016/j.joep.2011.02.004

Vehovec, M., Rajh, E., \& Škreblin Kirbiš, I. (2015). Financijska pismenost građana u Hrvatskoj (Financial literacy of Croatian citizens). Privredna kretanja i ekonomska politika, 24(1) 136, 53-75.

\section{Odnos između financijskoga zadovoljstva i financiiske pismenosti: istraživanje rodnih razlika}

Ivona ŠKREBLIN KIRBIŠ

Zagrebačka škola ekonomije i managementa, Zagreb

Maja VEHOVEC

Ekonomski institut, Zagreb

Zvonimir GALIĆ

Filozofski fakultet, Zagreb

Ciljevi rada bili su istražiti rodne razlike u komponentama financijske pismenosti (financijsko znanje, financijski stavovi i financijsko ponašanje) i financijskom zadovoljstvu te istražiti rodne razlike u odnosu između financijskoga zadovolistva i komponenti financijske pismenosti. Analiza podataka prikuplienih na velikom heterogenom uzorku hrvatskih građana $(\mathrm{N}=900)$ pokazuje da muškarci postižu bolje rezultate na nekim varijablama financijske pismenosti i iskazuju veće financijjko zadovoljstvo u odnosu na žene. Nadalje, u uzorku muškaraca utvrđene su više korelacije između financijskoga zadovoljstva i pojedinih varijabli financijske pismenosti (racionalni financijski stav, samoprocjena upravljanja financijama i praćenje troškova) u odnosu na uzorak žena. Osim demografskih varijabli, značajni prediktori financiijskoga zadovolistva kod oba roda jesu prije svega financijska ponašanja. Komponenta financijskoga stava objašnjava dodatnu varijancu financijske pismenosti za muškarce, ali ne i za žene. Financijsko znanje kao treća komponenta nije značajan prediktor financijskoga zadovoljstva ni za muškarce ni za žene.

Ključne riječi: financijska pismenost, financijsko zadovoljstvo, rodne razlike

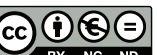

Međunarodna licenca / International License:

Creative Commons Attribution-NonCommercial-NoDerivatives 4.0. 